УДК 342.95

DOI https://doi.org/10.32849/2663-5313/2020.4.28

Руслан Пилипів,

канд. юрид. наук, дочент кафедри правознавства

Івано-Франківської філії

Відкритого міжнародного університету розвитку людини «Україна»

\title{
РЕАЛІЗАЦІЯ АДМІНІСТРАТИВНОЇ ВІДПОВІДАЛЬНОСТІ ЗА НЕСПЛАТУ АЛІМЕНТІВ
}

Проблема сплати аліментів натепер досить гостро сприймається украйнським суспільством, зокрема багатьма розлученими сім'ями з дітьми. Це питання є об'єктом міжгалузевого правового регулювання, значний відсоток якого припадає на норми адміністративного права. Одним із засобів такого забезпечення є інститут стягнення аліментів у примусовому порядку. Останнім часом до законодавства України було внесено чимало змін, які істотно впливають на иі правовідносини, що зумовлює актуальність подальших наукових розвідок у иьому напрямі адміністративно-правових досліджень. Метою дослідження є визначення характерних особливостей складу адміністративних правопорушень, передбачених статтею 183-1 Кодексу Украӥни про адміністративні правопорушення, та окреслення шляхів розв'язання проблемних питань їх застосування. У статті звертається увага на порядок встановлення та стягнення аліментів. Розглянуто особливості складу адміністративних правопорушень, пов'язаних з несплатою аліментів, визначено низку проблем правового застосування статі 183-1 Кодексу України про адміністративні правопорушення, окреслено шляхи їх вирішення. Зокрема, пропонується провести моніторинг навантаження персоналу територіальних органів Державної виконавчої служби та переглянути їх штатні нормативи та функціональні обов'язки в частині оформлення матеріалів за статтею 183-1 Кодексу України про адміністративні правопорушення. Також висловлюється позичія з приводу того, що під час притягнення осіб до адміністративної відповідальності за вказаною статтею має зазначатися заборгованість по несплаті аліментів на утримання дитини, яка виникла після набуття чинності зазначеної норми про адміністративну відповідальність. Підкреслено, що під час оформлення адміністративного правопорушення або прийняття рішення у справі слід з'ясовувати наявність чи відсутність обставин, які з поважних причин унеможливлювали для боржника сплату аліментів, чи наявну заборгованість по аліментах за минулий період. Обгрунтовується доиільність розробки методичних рекомендацій для органів місцевого самоврядування щодо порядку визначення та виконання суспільно корисних робіт.

Ключові слова: адміністративна відповідальність, аліменти, діти, несплата, правопорушення.

Постановка проблеми. Кожна дитина в світі потребує підтримки з боку своїх батьків. Це є її правом, яке забезпечується великою кількістю нормативно-правових актів як на національному, так і на міжнародному рівнях. Зазвичай ця підтримка базується на принципах моралі та відповідальності. Вона може бути фінансовою, моральною, забезпечувальною тощо. Але іноді бувають випадки, коли батьки не живуть разом та один з них не може у повному обсязі брати участь у житті дитини. Для такої категорії відносин у законодавстві України передбачений так би мовити альтернативний вид підтримки (фінансової) у вигляді щомісячної сплати коштів на дитину, а саме аліментів. Це мінімально прийнятна форма участі одного з батьків у процесі забезпечення життєдіяльності та становлення дитини. Проте процес оформлення та отримання аліментів часто видається емоційно важкою процедурою для багатьох жінок (рідше - чоловіків), які потрапили у подібне становище. На жаль, не завжди один з батьків може або бажає добровільно сплачувати аліменти. Тоді цей обов'язок покладається на них судом (у примусовому порядку).

Проблема сплати аліментів натепер досить гостро сприймається українським суспільством, зокрема багатьма розлученими сім'ями з дітьми. Це питання є об'єктом міжгалузевого правового регулювання, значний відсоток якого припадає на норми адміністративного права. 3 кожним роком держава все більше приділяє уваги належному забезпеченню прав дітей різними правовими шляхами. Одним із засобів такого забезпечення $€$ інститут стягнення аліментів у примусовому порядку. Це зумовлює поглиблений науковий інтерес до таких категорій, як «аліменти», «утримання дитини» та «адміністративна відповідальність за невиконання аліментного зобов'язання». 
Аналіз останніх досліджень. Інститут сплати аліментів та проблем адміністративно-правового регулювання аліментних відносин, а також виконання рішень судів, пов'язаних з утриманням дітей, завжди привертали увагу як вітчизняних, так і закордонних науковців. Серед учених, які вивчали поняття та порядок сплати аліментів, можна назвати О.О. Дерій, Т.C. Андрущенко, Г.М. Ахмач, Л.В. Афанасьєва, Н.Ш. Бахман, В.П. Нікітіна та інших. Однак останнім часом до законодавства України було внесено чимало змін (наприклад, збільшення мінімального розміру аліментів, спрощення процедури їх отримання і посилення відповідальності за їх несплату, запровадження реєстру для злісних неплатників аліментів та тих, хто ухиляється від їх сплати), які істотно впливають на ці правовідносини, що зумовлює актуальність подальших наукових розвідок у цьому напрямі адміністративно-правових досліджень. Серед останніх робіт нами було проаналізовано публікації таких авторів, як А.С. Ярошенко, О.М. Костенко, В.О. Спасенко тощо.

Метою статті $є$ визначення характерних особливостей складу адміністративних правопорушень, передбачених нормами (частинами) ст. 183-1 Кодексу України про адміністративні правопорушення (далі - КУПАП), та окреслення шляхів розв'язання проблем| них питань їх правореалізації.

Виклад основного матеріалу. На території України діє Конвенція ООН про права дитини, яка встановлює право кожної дитини на достатній рівень життя задля правильного розумового, духовного, соціального та морального розвитку дитини [1] Усім добре відомо, що батьки зобов’язані утримувати свою дитину до досягнення нею вісімнадцяти років, тобто повноліття. Цей обов'язок закріплено у ст. 51 Конституції України, ст. 180 Сімейного кодексу України (далі - СКУ). На чоловіка та дружину, які живуть єдиною родиною, такий обов'язок покладається рівномірно. Вони спільними коштами забезпечують усі потреби дитини. Але батьки зобов'язані утримувати дитину незалежно від того, одружені вони чи розлучені. Як тільки дитина залишається на утриманні одного з батьків, одразу набуває значення питання про виконання свого обов'язку іншим. Такий обов'язок може виконуватися як добровільно, наприклад за спільною домовленістю розлучених батьків (що відповідає ст. 181 СКУ), так і у примусовому порядку за рішенням суду.

Згідно зі статистичними даними після відкриття Єдиного реєстру боржників у 2018 році, кількість осіб, які є боржниками з виплати аліментів по Україні, становила 86,1 тис. У 2019 році така кількість збільшилася удвічі і сягнула 169,9 тис. осіб. Станом на 31.01.2020 р. кількість боржників нараховує 165,5 тис. осіб [2].

Якщо один 3 батьків відмовляється у добровільному порядку сплачувати аліменти, мотивуючи це недостатністю коштів, браком постійного доходу, скрутним особистим становищем, це зобов'язання стягується у судовому порядку. Зазвичай ці питання є об'єктом регулювання норм сімейного та цивільно-процесуального права. Але проблеми, які виникають з фактичним виконанням (реалізацією) таких судових рішень, зумовлюють підвищену увагу до цих відносин і з боку адміністративно-правового регулювання.

28 серпня 2018 року набрав чинності Закон України «Про внесення змін до деяких законодавчих актів України щодо створення економічних передумов для посилення захисту права дитини на належне утримання». Причинами прийняття цього нормативного акта стали систематичне ухилення батьків від виконання обов'язку стосовно утримання дитини, а також велика кількість невиконаних судових рішень за позовами щодо стягнення аліментів.

Саме на стадії виконання судового рішення у стягувача виникає найбільше проблем. Дотепер поширеними залишаються ситуації, коли платник аліментів ухиляється від виконання судового рішення стосовно стягнення аліментів. Усіх, хто має борг зі сплати аліментних зобов'язань, чекають обмеження особистого характеру. Зокрема, ті, хто не платить аліменти більше як 6 місяців, до моменту погашення заборгованості тимчасово позбавляються права виїжджати за кордон, керувати транспортними засобами, користуватися зброєю та полювати, вирішувати, чи має право його дитина виїжджати за кордон тощо. Разом із тим Законом України «Про внесення змін до деяких законодавчих актів України щодо посилення захисту права дитини на належне утримання шляхом вдосконалення порядку примусового стягнення заборгованості зі сплати аліментів» (набрав чинності 06.02.2018р.) КУПАП було доповнено новою статтею 183-1 [3]. Ця стаття $€$ новелою для адміністративно-деліктного законодавства, тому науковий інтерес викликає правова характеристика складу цього делікту та особливості його практичного застосування.

Положення вказаної норми (частини першої) встановлюють адміністративну відповідальність стосовно несплати аліментів 
на утримання дитини одного з подружжя або інших членів сім'ї, що призвела до виникнення заборгованості, сукупний розмір якої перевищує суму відповідних платежів за 6 місяців 3 дня пред'явлення виконавчого документа до примусового виконання. Частина друга ст. 183-1 КУпАП передбачає відповідальність за несплату аліментів на утримання дитини з інвалідністю, дитини, яка хворіє на тяжкі перинатальні ураження нервової системи, тяжкі вроджені вади розвитку, рідкісне орфанне захворювання, онкологічні, онкогематологічні захворювання, дитячий церебральний параліч, тяжкі психічні розлади, цукровий діабет I типу (інсулінозалежний), гострі або хронічні захворювання нирок IV ступеня, або на утримання дитини, яка отримала тяжкі травми, потребує трансплантації органа, потребує паліативної допомоги, що призвела до виникнення заборгованості, сукупний розмір якої перевищує суму відповідних платежів за три місяці 3 дня пред'явлення виконавчого документа до примусового виконання. За такі правопорушення законодавець встановив можливість призначення адміністративного стягнення у вигляді виконання суспільно корисних робіт на строк від 120 до 240 годин та від 240 до 360 годин залежно від частини. Кваліфікованим складом правопорушення (частина третя) є повторне протягом року вчинення правопорушення, передбаченого частинами першою або другою цієї статті. При цьому під повторним вчиненням правопорушення у цій статті слід розуміти невжиття особою заходів щодо сплати аліментів протягом двох місяців 3 дня відбуття адміністративного стягнення у вигляді суспільно корисних робіт, призначеного 3 підстав, передбачених цією статтею.

Об'єктом делікту є суспільні відносини у сфері громадського порядку та безпеки, а саме суспільні відносини, що забезпечують захист майнових інтересів неповнолітніх дітей або непрацездатних осіб, які потребують допомоги, а також відносини у сфері правосуддя, оскільки йдеться про невиконання судового рішення, яке набрало законної сили та належним чином звернуто до виконання [4, с. 282]. Для утворення об'єктивної сторони складу адміністративного правопорушення, передбаченого ст. 183-1 КУпАП, обов'язковим елементом є не тільки бездіяльність, а й суспільно шкідливі наслідки у вигляді великої заборгованості, сукупний розмір якої перевищує суму відповідних платежів за 6 місяців 3 дня пред'явлення виконавчого документа до примусового виконання. Шкода від наявної заборгованості трансцендує за межі родо- вого об'єкта передбаченого правопорушення (відносини у сфері громадського порядку та безпеки), оскільки неотримання протягом тривалого часу грошей родиною, де фактично дбають про дитину, суттєво впливає на задоволення її вітальних та інших потреб. Суб'єктом правопорушення є особа, яка на підставі пред'явленого до примусового виконання виконавчого документа зобов'язана сплачувати аліменти на утримання іншої особи. При цьому це може бути як батько, так і матір або навіть інші особи, що їх замінюють, у встановленому законом порядку. Суб'єктивна сторона правопорушення характеризується виною у формі умислу особа усвідомлює обов'язок сплати аліментних платежів. У цьому контексті слід чітко відмежовувати ті обставини, коли у особиплатника аліментів є об'єктивні або незалежні від нього причини несплати аліментів, як-от: тяжка хвороба, воєнні дії, надзвичайна ситуація (карантин), економічна криза в країні тощо. У разі наявності цих фактів протокол про адміністративне правопорушення за ст. 183-1 КУпАП не складається. У разі встановлення таких обставини під час вирішення справи суд повинен винести постанову про закриття справи у порядку, передбаченому ст. 284 КУПАП

E низка проблем правового та організаційного характеру, яка ускладнює фактичну реалізацію адміністративної відповідальності за несплату аліментів.

По-перше, це надмірна завантаженість персоналу підрозділів Державної виконавчої служби. Державним виконавцям, на яких, до речі, покладається обов'язок оформлювати матеріали (складати протоколи) про відповідні адміністративні правопорушення, критично не вистачає на це часу. Отже, постає питання про можливе введення додаткових посад до територіальних підрозділів цієї служби.

По-друге, натепер судова практика щодо притягнення осіб до адміністративної відповідальності за ст. 183-1 КУпАП є неоднозначною. Зокрема, деякі суди у мотивувальній частині рішення вказують на те, що адміністративне правопорушення, передбачене цією статтею, є триваючим правопорушенням. Згідно з листом Міністерства юстиції України від 02.08.2013 р. № 6802-0-4-13/11, триваючим визначаються правопорушення, які, почавшись 3 якоїсь протиправної дії або бездіяльності, здійснюються потім безперервно шляхом невиконання обов'язку [5]. Водночас А.С. Ярошенко, О.М. Костенко слушно наголошують, що пов'язувати час учинення такого правопорушення виключно 3 настанням і триванням суспільно шкідливих наслідків у вигляді 
заборгованості було б неправильним, оскільки в цьому разі об'єктивна сторона правопорушення розпочинається значно раніше і утворюється тільки у разі виникнення обумовленої заборгованості [4, с. 282].

По-третє, не має остаточного вирішення питання врахування часу виникнення заборгованості зі сплати аліментів (до чи після законодавчої деліктолізації діянь, передбачених ст. 183-1 КУпАП). Низка авторів не безпідставно вказують на порушення конституційних засад у судовій практиці у разі, якщо до адміністративної відповідальності притягають боржників за заборгованість, яка утворилась до лютого 2018 року, адже закон, який встановлює відповідальність, зворотної дії не має [4, с. 282 6, с. 213]. Проте Міністерство юстиції України має іншу позицію. Екс-заступник Міністра юстиції С.В. Глущенко зазначала що якщо на момент набрання чинності Законом в особи наявна заборгованість за несплату аліментів, сукупний розмір якої перевищує суму відповідних платежів за шість місяців 3 дня пред'явлення виконавчого документа до примусового виконання, то така особа після набрання чинності Законом має вжити необхідних заходів щодо погашення такої заборгованості. У разі невжиття цих заходів така особа має нести адміністративну відповідальність відповідно до статті 183-1 КУПАП [7].

По-четверте, у зв'язку з прийняттям зазначеної норми державні виконавці зіткнулися з проблемою щодо виконання суспільно корисних робіт. Адже органи місцевого самоврядування не в повному обсязі готові до пошуку та організації роботи, яка повинна бути оплачуваною для правопорушників, які мають заборгованість по аліментах. Щоб цього уникнути і зробити це можливим, органи виконавчої влади мають проводити відповідну роз'яснювальну роботу та надавати відповідну методологічну допомогу органам місцевого самоврядування в організації вирішення цього питання.

\section{Висновки}

3 огляду на вищевикладене, слід констатувати, що поряд з іншими адміністративно-правовими (обмежувальними) заходами запровадження адміністративної відповідальності за несплату аліментів своєчасним та потрібним засобом є створення необхідних правових умов для достатнього рівня життя та забезпечення прав і інтересів дітей. А сприяти цьому повинні їхні батьки незалежно від того, у яких стосунках вони перебувають.

Наша позиція з приводу наведених у цій статті проблемних питань полягає у такому:
1) необхідно провести моніторинг навантаження персоналу територіальних органів Державної виконавчої служби та переглянути їх штатні нормативи та функціональні обов'язки в частині оформлення матеріалів за ст. 183-1 КУПАП;

2) під час притягнення осіб до адміністративної відповідальності за ст. 183-1 КУпАП має зазначатися заборгованість 3 несплати аліментів на утримання дитини, яка виникла після набуття чинності зазначеної норми про адміністративну відповідальність;

3)під час оформлення адміністративного правопорушення/прийняття рішення у справі слід з'ясовувати наявність чи відсутність обставин, які з поважних причин унеможливлювали для боржника сплату аліментів, чи наявну заборгованість по аліментах за минулий період;

4) Міністерству юстиції України доцільно розробити методичні рекомендації для органів місцевого самоврядування щодо порядку визначення та виконання суспільно корисних робіт.

Будь-які нововведення та зміни до адміністративного законодавства можуть мати певні вади, шляхи їх вирішення є перспективними напрямами наших подальших наукових досліджень.

\section{Список використаних джерел:}

1. Конвенція ООН про права дитини від 20.11.1989 p. URL: https://zakon.rada.gov.ua/laws/ show/995_021 (дата звернення: 25.03.2020).

2. Усе про аліменти в 2020 році: розміри нарахувань, покарання боржників, примусові виплати. Слово $i$ діло: аналітичний портал. 1 лют. 2020. URL:https://www.slovoidilo.ua/2020/02/01/ infografika/suspilstvo/use-pro-alimenty-2020roczi-rozmiry-naraxuvan-pokarannya-borzhnykivprymusovoyi-vyplaty (дата звернення: 25.03.2020).

3. Про внесення змін до деяких законодавчих актів України щодо посилення захисту права дитини на належне утримання шляхом вдосконалення порядку примусового стягнення заборгованості зі сплати аліментів : Закон України від 07.12.2017 р. № 2234-VIII. URL: https://zakon.rada.gov.ua/laws/ show/2234-19 (дата звернення: 25.03.2020).

4. Ярошенко А.С., Костенко О.М., Гасанов Е.Д., Калашнік Р.В. Особливості адміністративної відповідальності за несплату аліментів в Україні. Порівняльно-аналітичне право. 2018. № 2. C. 281-284

5. Щодо надання роз'яснення положень Кодексу України про адміністративні правопорушення : Лист Міністерства юстиції України; Витяг від 02.08.2013 р. № 6802-0-4-13/11. URL: https://zakon.rada.gov.ua/laws / show / v6802323-13 (дата звернення: 28.03.2020).

6. Спасенко В.О. До питання суспільно корисних робіт як виду адміністративних стягнень. 
Юридичний бюлетень. 2019. Вип. 9. С. 209-213. DOI: https://doi.org/10.32850/2414-4207.2019-9.27.

7. У Мін'юсті обговорили практику застосування законодавства у сфері аліментів: новини
Міністерства за 04.04 .2018 p. URL: https:// minjust.gov.ua/news/ministry/v-minyusti-obgovorilipraktiku-zastosuvannya-zakonodavstva-u-sferistyagnennya-alimentiv (дата звернення: 28.03.2020).

The problem of alimony payments is to date very acute in the Ukrainian society, including many divorced families with children. This issue is the subject of cross-industry legal regulation, a significant percentage of which falls under the rules of administrative law. One of the means of such security is the institute of forced maintenance of alimony. Recently, a lot of changes have been introduced to the legislation of Ukraine, which significantly affect these legal relationships, which makes the relevance of further scientific investigations in this area of administrative and legal research. The purpose of the study is to determine the specific features of the composition of administrative offenses provided for in Article 183-1 of the Code of Administrative Offenses and to outline ways of solving problematic issues of their application. The article drawes attention to the procedure for installing and recovering alimony. The peculiarities of the composition of administrative offenses related to non-payment of alimony are considered, a number of problems of legal application of Article 183-1 of the Code of Administrative Offenses are determined, the ways of their solution are outlined. In particular, it is proposed to monitor the workload of the staff of the territorial bodies of the State Bailiffs' Service and to review their staff standards and functional obligations regarding the registration of materials under Article 183-1 of the Code of Administrative Offenses. The position is also expressed that when arraignment of persons under administrative responsibility for the said article, the debt for non-payment of child support, which arose after the entry into force of the said rule on administrative responsibility, should be noted. It is emphasized that when making an administrative offense or taking a decision in a case, it is necessary to find out the presence or absence of circumstances which, for good reasons, made it impossible for the debtor to pay alimony or existing arrears. The expediency of developing methodological recommendations for the local self-government bodies on the procedure for identifying and performing socially useful works is substantiated.

Key words: administrative responsibility, alimony, children, non-payment, offenses. 